\title{
The Cape Supergroup in Natal and the Northern Transkei
}

SIR,-The rocks of the so-called Cape System (Cape Supergroup) of South Africa outcrop in two coastal belts, separated by $300 \mathrm{~km}$ of younger rocks (see map). In Cape Province, a full succession has been described (see Table 1), extending from possible Lower Cambrian to Upper Devonian. The Natal sequence is incomplete, and consists of 'thick ... sandstones, with grits and conglomerates' (Anderson, 1901), resting on Precambrian rocks and overlain by Karroo strata. In his First Report of the Geological Survey of Natal and Zululand, Anderson (1901) observed that: 'Petrologically, they are very unlike the quartzites and grits of the Table Mountain Sandstones of Cape Colony.' In his Second Report, however, Anderson (1904) concluded: '. . I I think that there is no doubt as to the correlation of the formation spoken of in my first report as "Palaeozoic Sandstones", with the Table Mountain Sandstones of Cape Colony'. No palaeontological evidence existed to confirm or disprove this identification, but subsequent authors have accepted Anderson's conclusions, and reference to the 'Table Mountain Sandstones of Natal' is encountered commonly.

Late in 1970, a few poorly preserved fossils were found by quarry workers at a locality about $5 \mathrm{~km} \mathrm{~W}$ of Port St Johns, in Pondoland. Originally thought to be fish, they were sent to Grahamstown, where they were identified as protolycopods. Similar lycopsids are known from the upper parts of the Bokkeveld Group, and from the Witteberg Group. Although rare lycopsids have been recorded from the Early Devonian, the class did not become abundant until later in the period; it is thus improbable that any strata containing lycopsids are correlatives of the pre-Devonian Table Mountain Group. It is likely that the Natal rocks are lateral equivalents of the Witteberg Group of Cape Province.

The fossils were first shown to the writer by Dr R. A. Jubb. Acknowledgement is due also to Mr M. A. Meyer, of the Albany Museum, Grahamstown, for helpful discussions and to Dr E. Plumstead, who is carrying out detailed studies of the material.

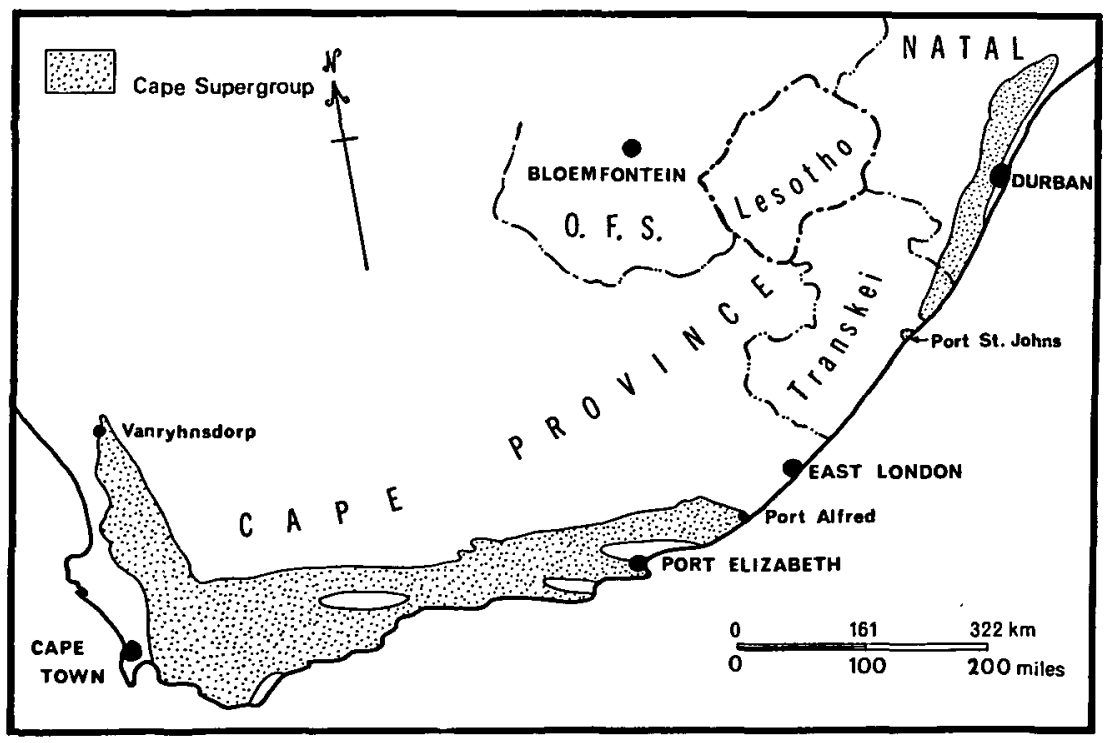

Figure 1. Map of part of South Africa, showing the distribution of the Cape Supergroup.

Geol. Mag. 110 (5), 1973, pp. 485-486. Printed in Great Britain. 
Table 1. Outline stratigraphy of the Cape Supergroup of Cape Province, South Africa

\begin{tabular}{llll}
\hline \multicolumn{1}{c}{ Rock units } & \multicolumn{1}{c}{ Lithologies } & \multicolumn{1}{c}{ Ages } \\
\hline Karroo supergroup & & $\begin{array}{l}\text { Early Carboniferous } \\
\text { and younger }\end{array}$ \\
\hline Witteberg Group & $\begin{array}{l}\text { Non-marine ortho- } \\
\text { quartzitic sandstones, } \\
\text { with shale units at } \\
\text { base and top }\end{array}$ & $\begin{array}{l}\text { ?Middle to Late } \\
\text { Devonian }\end{array}$ \\
\cline { 2 - 4 } $\begin{array}{l}\text { Cape } \\
\text { super- } \\
\text { group }\end{array}$ & Bokkeveld Group & $\begin{array}{l}\text { Non-marine shales, } \\
\text { with sandstone units }\end{array}$ & \\
\cline { 2 - 4 } & $\begin{array}{l}\text { Marine shales, with } \\
\text { sandstone units }\end{array}$ & Early Devonian \\
\cline { 2 - 3 } & Table Mountain Group & $\begin{array}{l}\text { Ortho-quartzitic } \\
\text { sandstones, with shale } \\
\text { units }\end{array}$ & $\begin{array}{l}\text { Late Cambrian to } \\
\text { Late Silurian* }\end{array}$ \\
\end{tabular}

* See Cocks and others, 1970.

\section{References}

Anderson, W. 1901. First Report of the Geological Survey of Natal and Zululand. Pietermaritzburg, $137 \mathrm{pp}$.

1904. Second Report of the Geological Survey of Natal and Zululand. London. $169 \mathrm{pp}$. Cocks, L. R. M., Brunton, C. H. C., Rowell, A. J. \& Rust, I. C. 1970. The first Lower Palaeozoic fauna proved from South Africa. Q. Jl geol. Soc. Lond. 125 (for 1969), 583-603.

Department of Geology

BRIAN E. LOCK

Rhodes University

Grahamstown

South Africa

11th December 1972 